p-ISSN 1693-9484, $e$-ISSN : 2621-8313

Majalah Ilmiah Bahari Jogja (MIBJ)

Vol. 19 No. 1, Februari $2021 \quad$ (19-24)

DOI: $0.33489 /$ mibj.v19i1.235

(C) 2021 Sekolah Tinggi Maritim Yogyakarta

\title{
IMPLEMENTATION OF THE STRONG COASTAL DEVELOPMENT PROGRAM IN THE EFFORTS TO DEVELOP COASTAL AREAS AS POVERTY REDUCTION EFFORTS IN CENTRAL JAVA PROVINCE
}

\author{
Kundori $^{{ }^{*} \text {, Arika Palapa }}{ }^{2}$ \\ ${ }^{1}$ Universitas Maritim Amni Semarang, Jl. Sukarno - Hatta No. 180 Pedurungan \\ Semarang 50246, Indonesia \\ E-mail : kundori.jaken@gmail.com. Telp : +6285225146791 \\ ${ }^{2}$ Politeknik Ilmu Pelayaran Semarang, Jl. Singosari raya No. 2A Semarang 50242, \\ Indonesia \\ *Corresponding Author. E-mail : arikapalapa67@gmail.com. Telp : +628122816138
}

\begin{abstract}
Coastal villages have different characteristics from villages in rural areas. This difference is not only on the geographical-ecological aspect, but also on economic and socio-cultural characteristics. Geographically, coastal villages are on the border between land and sea. Geographical-ecological conditions of coastal villages affect economic activities in them. Economic activities in coastal villages are characterized by activities in the utilization of coastal environmental resources and services. Economic activities include fisheries, trade, maritime tourism, and transportation This study seeks to study the application of tough coastal development programs as an effort to build an oriented coastal region to facilitate the economic activities of villages in coastal areas that are expected to reduce the poverty rate of coastal communities in the middle of the city. This study uses a qualitative research design using descriptive methods that intend to explain how the phenomenon of resilient coastal village development and coastal area development as an effort to reduce the number of coastal communities in Central Java province by using purposive sampling sampling techniques and research samples taken in coastal communities The results of the north coast of Java and cilacap districts were as follows: that the implementation of the strong Coastal Village Development Program in the coastal communities of Central Java showed that the three focuses of development activities had been carried out properly. The development activities are resource development, environmental / infrastructure development, and disaster preparedness development. While activities that are not carried out are human development and business development. The recommendations given in this study are that the implementation of the program must be supported by sufficient funds, need coordination and cooperation with other stakeholders, and the need for effective monitoring and evaluation
\end{abstract}

Keywords: program implementation, coastal village, coastal area development, Poverty, Central Java

\section{INTRODUCTION}

About two-thirds of Indonesia's territory is marine and contains abundant marine resources compared to our neighboring countries such as Malaysia and 
other ASEAN countries. Large marine potential and a high level of exports are not accompanied by the welfare of fishermen, especially small fishermen or traditional fishermen. The socio-economic level in Indonesian fishermen's life is relatively low. The work pattern of fishermen who are very tied to catching fish in the sea, limits the activities of fishermen to other occupational sectors. This is different from the community working in agriculture, where after the planting season and waiting for harvest time to do odd jobs as a source of income. Coastal communities, most of which are fishing communities, are generally disadvantaged groups at the lowest level, both left behind economically, socially, and culturally. The low standard of living of coastal communities and limited access to assets and funding sources for small fishermen is a major problem in the coastal region. With income that still depends on natural conditions, it is difficult for them to change their lives for the better. As traditional fishermen, they are not only faced with the uncertainty of income and the pressure of a long fish famine season, but also with financial management issues and the marketing of their products.

Fishermen who cannot transfer to other jobs affect their household income and expenditure, as a result fishermen are in a circle of poverty (Kusnadi, 2002). There are many factors that influence the poverty trap of fishing communities, including the fluctuations in fish season, limited human resources, limited access to financial institutions and capital, and the impact of modernization of fisheries which causes excessive depletion of marine resources (Dimyati, 2015) . Government programs regarding the economic empowerment of the coastal community (PEMP) should aim at the welfare of coastal communities through the development of economic activities, improving the quality of human resources and strengthening socio-economic institutions by utilizing marine and fisheries resources optimally and sustainably, but in reality Government programs that should be routine from the government are often only conditional and do not have a significant impact. Based on the above problems, the purpose of the research is to find out the effectiveness and sustainability of the programs carried out by the government in the economic empowerment of the poor (fishermen) on the coast of Central Java.

\section{RESEARCH METHOD}

The location of the research will be carried out In the community of the north coast of Central Java (Tegal, Pekalongan, Pati, Kendal and Cilacap district), the new focus of research is community empowerment in fisheries product management. The type of research used is a qualitative descriptive approach, which is intended for careful measurement of case studies of certain social phenomena. The data source of this study is mainly filtered from primary data sources and secondary data in proportion to the purpose of this study (Hakim et al., 2020). Furthermore, the data collection technique used in this study is: observation, namely making observations directly in the field according to the object under study; interviews, namely interviews directly with informants using interview notes and guidelines; Documentation, namely the study of literature / literature, documents, and other written sources that are related to the needs of data and information in this study (Sugiyono, 2012). Data analysis was carried out 
by examining data obtained from various sources or information from the results of good research obtained through primary data and secondary data carried out descriptively qualitative. The data analysis technique in this study uses the Miles et al model, where the data obtained is analyzed qualitatively, namely data analysis is carried out interactively and continues continuously to completion. The process sequence includes data reduction, data presentation, and data verification (Sugiyono, 2012).

\section{RESULT AND DISCUSSION}

The factors that influence the effectiveness of the fishing community empowerment program in Central Java are as follows:

1. Resources.

Resources are a very important factor in implementing a work program, this is because the implementation of work programs tends to be less effective if there is a lack of resources in implementing the program activities. In the implementation of the fishing community empowerment program activities in the coastal communities of Central Java province it turned out that most of the activities carried out were ineffective, this was due to lack of implementing resources for program activities, fishing community resources involved in fishing community empowerment program activities, including lack of financial resources and facilities for the implementation of the fishing community empowerment program program activities. In the implementation of program activities, the Implementing Party in this case the coastal community had previously received no training on program implementation, fund management, lack of conducting guidance for the community which would be included in the activities of the fishermen community empowerment program in Central Java province.

2. Supervision.

In each implementation of activities it is necessary to have supervision activities to find out whether the implementation of the activity program is carried out properly or there are deviations. Regarding the supervision, the implementation of the Central Java Province coastal community empowerment program was less effective.

3. Communication.

Communication is important for the implementation of an activity program with good communication, so that the clarity of the information needed is obtained. The implementation of the Central Java Province coastal community empowerment program shows that communication between the implementers and the Kelurahan ( village) / Kabupaten( Regency) has not been good, so this has resulted in misscommunication between the coastal community empowerment program implementers in Central Java and the Districts, to the fishing community as targets community empowerment.

Sustainability Analysis of Community Empowerment Looking at implementation the cycle of community empowerment and community capacity building that exists in Central Java coastal communities today, the community is actually ready to continue the empowerment program in their village. This

Majalah Ilmiah Bahari Jogja 21 | http://jurnal.amy.ac.id/index.php/MIBJ/ 
conclusion is supported by the awareness of the community to work in groups. The sustainability of the community empowerment program in the village is also related to the desire of the community to form cooperatives as a vehicle for managing their finances and helping each other between coastal communities if they need financial assistance. The initiative to form cooperatives is based on the desire of the community to be released from loan assistance in the form of ensnared debt from employer fishermen. With cooperatives it is also possible to establish support and cooperation involving government and non-government funding institutions. Currently a cooperative with a sharia system in the form of BMT (baitul maal wa tamwil) and there is also a form of a conventional savings and loan cooperative with the same name as the Bina Nelayan Group, which has been serving capital and savings and loans for fishermen. This cooperative also provides sales of some items needed for fishing activities such as nets, ropes, ballast and so on. The next indicator that shows the sustainability of the empowerment of coastal communities in Central Java province is the trust of the government, both the central government, the provincial government, and the district government. This is indicated by several activities carried out to improve human resources in the coastal marine in central java so that it affected the people in other hamlets. Government activities launched such as education and training activities, activities for providing fishing gear and fishing boat assistance, education and training activities for women fishermen, fisheries processing business activities and others.

\section{CONCLUSION}

Based on the results of the research and discussion that has been explained, the authors draw conclusions as follows: The empowerment program of fishermen communities in central java, like in Pati , Tegal, Pekalongan and Cilacap Regency has not been effective, this can be seen from the lack of resources for implementing the empowerment program for fishing communities in central java, the average level of education being graduated from high school. This resulted in the difficulty of delivering information on the program of empowering fishermen communities to fishing communities in the coastal areas of central java as the target of empowering the poor. The Central Java Province coastal community empowerment program is less effective in conducting training activities. This can be seen from the lack of interest of the coastal fishermen community to attend the training held, only some of them attended the training, this was compounded by Instructors who are often late even rarely present to provide training on busy reasons outside. The factors that influence the implementation of the coastal community community empowerment program in Central Java province are: Resources, supervision factors, communication factors.

\section{ADVICE}

The indicator that shows the sustainability of the empowerment of coastal communities in Central Java province is the trust of the government, both the central government, the provincial government, and the district government. This 
is shown from several activities carried out to improve human resources in the coastal communities of Central Java province so that it affects the community. Government activities launched such as education and training activities, activities for providing fishing gear and fishing boat assistance, education and training activities for women fishermen, fisheries processing business activities and others.

\section{ACKNOWLEDGMENT}

Our gratitude goes to all the research teams and colleagues who have helped the smooth process of this research.

\section{REFERENCE}

Aminah, Siti, 2010. Strategi Pemberdayaan Nelayan Berbasis Keunikan Agroekosistem dan Kelembagaan Lokal. Laporan Penelitian, IPB Bogor.

Afifi, Mansur. dan Latifah, Siti, 2011. Peranan Kelembagaan bagi Pengembangan Sumber Daya Non Material dalam Menunjang Pembangunan Perdesaan. Jurnal Sosiohumaniora Unpad, Vol. 13 No.3, 263 - 273.

Dokumen Penilaian Ketangguhan Kawasan, 2015. Kebumen : Dinas Kelautan dan Perikanan.

Djoeffan, Sri Hidayati, 2002. Strategi Partisipasi Masyarakat dalam Perencanaan Pembangunan di Indonesia. Jurnal Mimbar Unisba, Vol. 18 No.1, 54-77.

Juniarta, Hagi Primadasa, 2013. Kajian Profil Kearifan Lokal Masyarakat Pesisir Pulau Gili Kecamatan Sumberasih Kabupaten Probolinggo. Jurnal ECSOFi Vol. 1 No. 1, 11-25.

Marliana, Dian, 2013. Kebijakan Pengelolaan Wilayah Pesisir Berbasis Sustainable Development Di Kabupaten Sampang.JAP Jurnal Administrasi Publik Unibraw, Vol.1 No.3, 80-86.

Arikunto, Suharsimi,2002, Prosedur Penelitian, Suatu pendekatan Praktek, Edisi Revisi V,Rineka Cipta,, Jakarta

Hakim, A. R., Wibowo, W., Astriawati, N., Prodi, A., Kapal, P., Tinggi, S., ... Maritim, T. (2020). SISTEM PENDINGIN MESIN DIESEL PADA WHELL LOADER KOMATSU WA120-3CS. Teknovasi, Jurnal, 07, 7685.

Harahap,M.K. 2001. Kajian Partisipasi Masyarakat dalam Pengelolaan Hutan Mangrove (Studi Kasus diDesa Karangsong, Kecamatan Indramayu, Kabupaten Indramayu, Propinsi Jawa Barat ). Tesis Program Pascasarjana Institut Pertanian Bogor.

Islamy dkk., 2004, Prinsip-Prinsip Perumusan Kebijaksanaan Negara, Bumi Aksara, Jakarta

Keputusan Menteri kelautan dan Perikanan No 18 tahun 2004 tentang pedoman umum pemberday aan ekonomi Masy arakat pesisir (PEMP), Jakarta

Resosudarmo,B.P.,D.Hartono, T. Ahmad, N.I.L. Subiman, Olivia, A.Noegroho, 2002. Analisa Penentu Sektor Prioritas Di Kelautan Dan 
Perikanan Indonesia. Jurnal Pesisir dan lautan Volume 4 No.3 tahun 2002.

Riduwan, Rusyana,Enas,2011, Cara Mudah Belajar SPSS 17, dan Aplikasi Statistik Penelitian, Alfabeta, Bandung

Rosalina, Iga 2012, efektivitas program nasional pemberdayaan masyarakat mandiri Perkotaan pada kelompok pinjaman bergulir di dsa mantren kecamatan Karangrejo kabupaten magetaan, Jurnal Header. Volume 01 Nomor 01 Tahun 2012, 0 - 216

Sipahelut, 2010,Analisi Pemberdayaan Masyarakat Nelayan di Kecamatan Tobelo Kabupaten Halmahera Utara, Tesis Program Pascasarjana Institut Pertanian Bogor, Bogor

Sriwahyuni, Ajeng, 2015, Hubungan tingkat partisipasi masyarakat dan efektivitas kegiatan simpan pinjam perempuan program nasional pemberdayaan masyarakat (spp pnpm) mandiri di desa talagasari, kecamatan kadungora, kabupaten garut, Skripsi, Institut Pertanian Bogor

Sugiyono. (2012). Metode Penelitian Kuantitatif, Kualitatif dan R \&

D.Bandung:Alfabeta. Metode Penelitian Kuantitatif, Kualitatif Dan $R$ \&

D.Bandung:Alfabeta. https://doi.org/10.1017/CBO9781107415324.004

Sulistyowati, L. 2003. Analisis Kebijakan Pemberdayaan Masyarakat Dalam Pengelolaan Sumber Daya Alam Gugus Kepulauan (Studi kasus Kelurahan Pulau Kelapa dan Kelurahan Pulau Harapan Kecamatan Kepulauan Seribu Utara, Taman Nasional Laut Kepulauan Seribu. Disertasi Program PascaSarjana Institut Pertanian Bogor.

Sumiarti, 2008, Kajian Efektifitas Program Pemerintah Long Tail terhadap Masyarakat Nelayan Bungus, tesis Pasca sarjana Universitas Andalas Padang

Tulungen, J.J., T.G. Bayer, B.R.Crawford, M.Dimpudus, M.Kasmidi, C.Rotinsulu, A.Sukmara dan N. Tangkilisan.2002. Panduan Pembentukan dan Pengelolaan Daerah Perlindungan Laut Berbasis-Masyarakat. CRC Technical Report Nomor2236. Departemen Kelautan dan Perikanan Republik Indonesia dan Univesity ofRhode Island, Coastal Resources Center, Narragansett Rhode Island, USA 